\title{
Pengembangan Usaha Aneka Penganan Tradisional Minang Dalam Meningkatkan Ekonomi Masyarakat
}

\author{
Fera Sriyunianti ${ }^{1}$, Fauna Adibroto ${ }^{2}$, Zulfikar $^{3}$ \\ 1 Jurusan Akuntansi, Politeknik Negeri Padang \\ Email: ferasriyunianti@gmail.com \\ ${ }_{2}^{2}$ Jurusan Teknik Sipil, Politeknik Negeri Padang \\ Email:fauna adibroto@yahoo.com \\ ${ }^{3}$ Jurusan Teknik Mesin, Politeknik Negeri Padang \\ Email: zulfikarmansyur@yahoo.com
}

\begin{abstract}
There are so many home-based businesses in West Sumatra. One of them is to make traditional cakes typical of the local area. Minang Kabau have many culinary products that have been widely known. Starting small business with household business can be a successful business with many branches. However, not infrequently this business is well developed, and some even stopped. There are many weaknesses in this household business, from production to business management. Some problems are still using simple tool in production process, inefficient and unhygienic production layouts. Another problem is the packaging is simple and simplistic, unattractive the display of products and less professional management. The IbM's goal is to improve the professionalism of home-based cakes through factory layout improvements, coconut shell extract packaging, product sales / display counters, PIRTs, trademarks, bookkeeping, management, and product marketing.
\end{abstract}

Key words: production, lay-out product, display product, bookkeeping, small and medium enterprises

\begin{abstract}
ABSTRAK
Ada banyak sekali usaha rumahan yang sudah dilakoni oleh masyarakat Sumatera Barat. Salah satunya adalah membuat kue-kue tradisional khas daerah setempat. Minang kabau memiliki beraneka macam produk kuliner yang telah dikenal luas. Usaha yang dimulai kecil-kecilan dari rumah bisa sukses menjadi toko kue yang memiliki banyak cabang. Namun, tidak jarang usaha ini tidak berkembang dengan baik, bahkan ada yang berhenti begitu saja. Terdapat banyak kelemahan dalam usaha rumah tangga ini, mulai dari proses produksi sampai dengan manajemen usaha. Persoalan produksi yang dihadapi adalah proses produksi yang masih menggunakan alat sederhana, layout produksi yang tidak efisien dan hygienis. Persoalan lain adalah kemasan yang sederhana dan seadanya, tampilan produk yang tidak menarik serta manajemen pengelolaan yang masih belum professional. Tujuan kegiatan IbM ini adalah untuk meningkatkan profesionalitas usaha kue rumahan melalui pembenahan lay-out pabrik, alat pengupas kulit ari kelapa kemasan, konter penjualan / display produk, PIRT, merk dagang, pembenahan pembukuan, manajemen, dan pemasaran produk.
\end{abstract}

Kata kunci: produksi, lay-out produk, display produk, pembukuan, usaha kecil menengah

\section{PENDAHULUAN}

Cupak Tangah adalah salah satu Kelurahan di Kecamatan Pauh, Padang, Sumatera Barat, Indonesia. Pauh adalah sebuah kecamatan di kota Padang, Sumatera Barat, Indonesia. Sebelumnya wilayah kecamatan ini masuk ke dalam wilayah kabupaten Padang Pariaman, namun berdasarkan PP nomor 17 tahun 1980, sejak 21 Maret 1980 
menjadi wilayah administrasi kota Padang, dengan kota kecamatan terletak di Pasar Baru. Kecamatan Pauh berada dalam jarak $6 \mathrm{~km}$ dari pusat kota dan berbatasan langsung dengan kabupaten Solok. Areal hutan lindung dan hutan rakyat sangat dominan di kecamatan ini, yang meliputi $82 \%$ dari total luas wilayah kecamatan, sisa sebagian besar berikutnya adalah areal persawahan, kebun =dan ladang. Seiring dengan peningkatan jumlah penduduk di daerah Cupak Tangah. Hal ini memberikan dampak yang luar biasa terhadap perkembangan perekonomian masyarakat Pauh pada umumnya, dan cupak tangah secara khusus. Usaha kue rumahan di jalan Irigasi, kelurahan Cupak Tangah juga mulai dirintis. Namun perkembangannya hingga kini, tidaklah begitu berarti karena banyaknya kelemahan yang dimiliki oleh usaha ini. Usaha kue rumahan tersebut antara lain usaha kue Asnidar (Lomak's Kue) dan usaha kue Darnis (Pangacok). Tim IbM memberikan nama Lomak's kue dan Pangacok kepada kedua usaha kue rumahan tersebut. Usaha ke ini masih memiliki banyak kelemahan, baik dari sisi produksi, manajemen, maupun pemasaran. Produksi dilakukan menggunakan layout yang kurang efisien dan minimnya peralatan. Kemudian dari sisi manajemen, masih tradisional, tanpa ada perencanaan dan pembukuan. Kelemahan pada bidang pemasaran adalah tergantung pada toko tempat penitipan barang.

\section{PENGEMBANGAN USAHA ANEKA PENGANAN TRADISIONAL MINANG DALAM MENINGKATKAN EKONOMI MASYARAKAT}

\section{Potensi Mitra}

Usaha Kue Asnidar (Lomak;s Kue)

Usaha kue rumahan telah dirintis oleh Asnidar sejak tahun 1995, mulai dengan membuat kue pinukuik (sejenis pan cake) khas Padang, Sumatera Barat. Kemudian usaha ini menunjukan perkembangan yang berarti, sehingga bu Asnidar menambah jenis kue yang dibuatnya, yaitu kue Jaguang Karambia dan Silamak Baluwo. Semua kue dijual ke pasar raya padang yang berjarak $10 \mathrm{~km}$ dari rumah dan pasar raya gaung yang berjarak $11 \mathrm{~km}$ dari rumah. Semua kue dibawa dan tidak ada dilakukan penjualan di rumah.

\section{Usaha Kue Asnidar (Lomak;s Kue)}

Asnidar membuat kue yang trbuat dari ubi kayu, yaitu kue kolak bonai, onde ubi, dan lopis sipuluik. Kue ini juga dititpkan di warung dan masih terbatas pemasaranya.

\section{Metode Pelaksanaan}

Metode pendekatan yang ditawarkan adalah

1. Metode diskusi

2. Metode pelatihan

3. Metode perancangan dan pembuatan

4. Metode pembimbingan

Partisipasi mitra dalam pelaksanaan kegiatan adalah penyediaan tempat pengabdian masyarakat, penyediaan fasilitas penunjang pelaksanaan pengabdian sebagai peserta pelatihan dan juga mitra dalam pembuatan pembukuan dan perbaikan proses produksi. Kegiatan dilakukan disela waktu pembuatan kue, sehingga tidak mengganggu proses produksi mitra.

\section{Pengembangan yang dilakukan}

Pengembangan yang dilakukan meliputi 3 aspek, yaitu; 


\section{Produksi}

Pada aspek ini dilakukan perbaikan, yaitu;

1. Perancangan layout pabrik

Perancangan layout pabrik dilakukan agar mitra memiliki perencanaan ke depannya untuk membenahi layout yang kurang efisien.

Gambar 1 merupakan rancangan layout pabrik yang telah dibuat

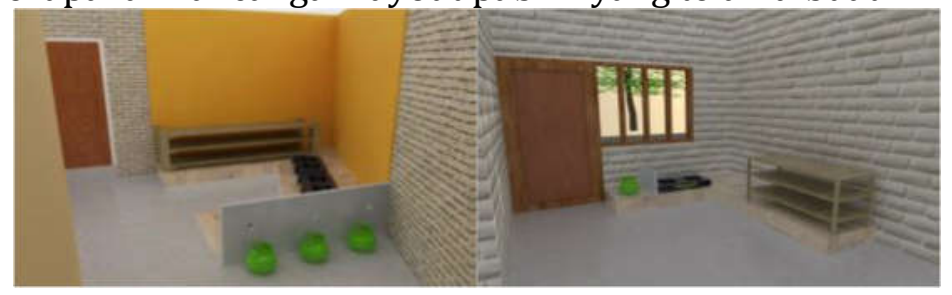

Gambar 1. Rancangan layout pabrik

2 Penambahan produk baru

Penambahan produk baru dilakukaan dengan cara memberikan pelatiha kepada mitra pada lembaga kursus kue yang ada di kota Padang. Dari hasil pelatihan ini ada tambahan 1 produk yaitu kue talam ubi, merah dan kue talam ubi ungu.

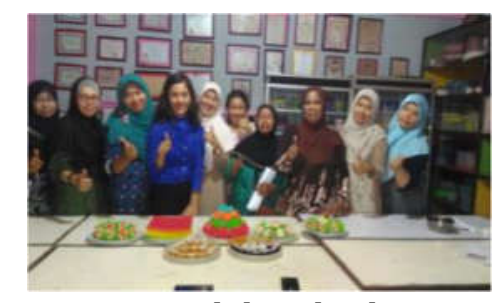

Gambar 2. Suasana setelah pelatihan pembuatan kue

3 Bantuan peralatan dan furniture pabrik

Bantuan peralatan berupa lemari dan kompor gas serta alat cetak kue. Adanya lemari ini menjadikan layout lebih baik dan rapi serta dapat digunakan untuk meyimpan peralatan yang ada. Sedangkan lemari tempat bahan baku jagung berguna untuk menyimpan jagung lebih aman dan higienis.

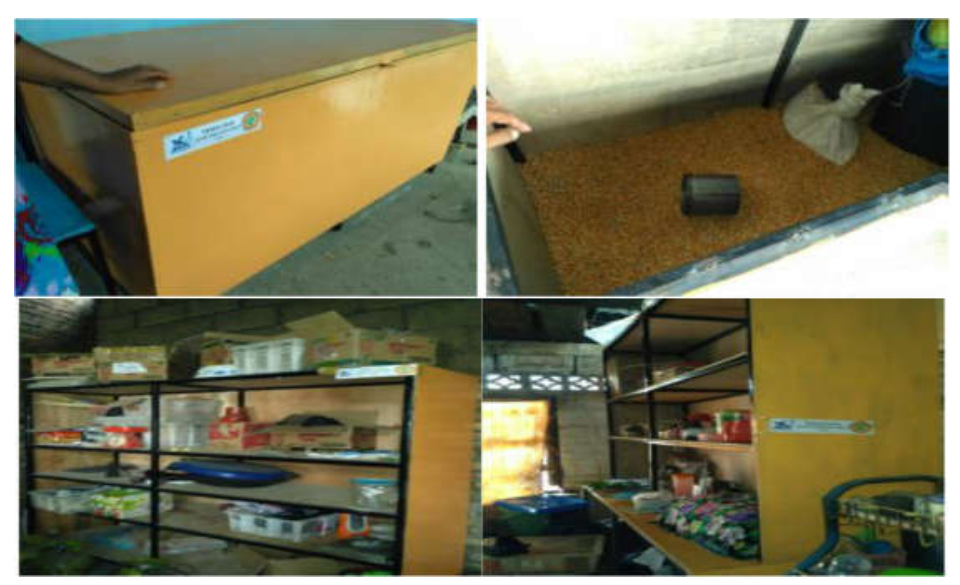


Gambar 3. Bantuan berupa furnitur pabrik

\section{Manajemen}

Pada aspek pemasaran, perbaikan yang dilakukan adalah:

1. Peningkatan kemampuan manajemen usaha (perencanaan, anggaran, dan pengelolaan keuangan, dan pemasaran)

Kegiatan ini sudah dilakukan dengan memberikan pelatihan perencanaan anggaran dan pengelolaan keuangan serta pemasaran secara sederhana kepada pemilik. Tujuan kegiatan ini adalah agar pemilik memiliki pengetahuan tentang penganggaran perusahaan.

2. Pembuatan pembukuan usaha Pembuatan pembukuan sudah dilakukan dengan membuatkan dan melatih pembukuan sederhana untuk usaha kecil. Materi pembukuan yang diberikan adalah pembukuan sederhana yang mudah dipahami oleh mitra. Hal ini mengingat kesibukan mitra yang menangani berbagai pekerjaan sekaligus, mulai dari produksi, pemasaran, sampai dengan mengelola usaha ini.

\section{Pemasaran}

Perbaikan yang dilakukan dalam hal pemasaran yaitu:

1 Pembuatan konter penjualan kue

Pada gambar berikut, terdapat etalase yang dapat digunakan mitra untuk menjual kue di rumah.

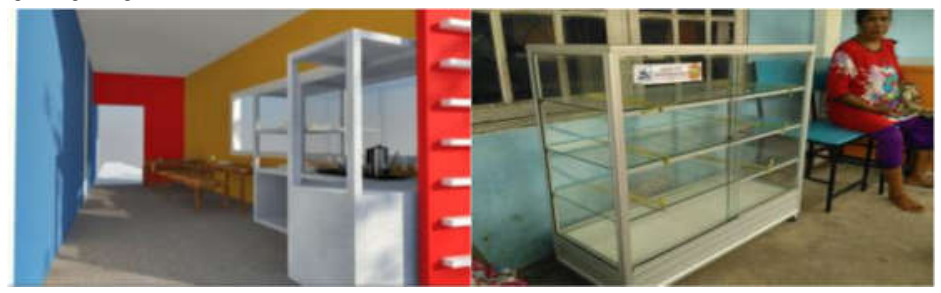

Gambar 4. Konter pemasaran kue

2. Bantuan modal kerja

Bantuan modal kerja diberikan kepada mitra agar lebih termotivasi untuk mulai pembuatan kue baru. Hasil dari kegiatan ini menambah omset penjualan mitra, yaitu sekitar Rp.120.000- Rp. 140.000 per hari. Sebelumnya penjualan mitra berkisar. Kegiatan ini memiliki beberapa kendala dalam hal identifikasi kebutuhan mitra. Perlu komunikasi yang lebih inten antara pelaksana dan mitra sehingga perencanaan kegiatan pengabdian betul-betul sesuai dengan kebutuhan mitra. Kendala lain adalah keterbatasan tenaga kerja, karena semua kegiatan dilakuka oleh satu orang, perlu kaderisasi dan pelatihan bagi keluarga lain sehingga dapat membantu kelancaran usaha.

$3 \quad$ Pembuatan merk dagang

Merk dagang dibuat agar usaha mitra memiliki identitas yang jelas sehingga dapat dikenal oleh masyarakat secara luas. Merk dibuat menyesuaikan dengan ukuran kemasan pada kue. Gambar 3 menunjukkan contoh merk dagang yang dirancang. 


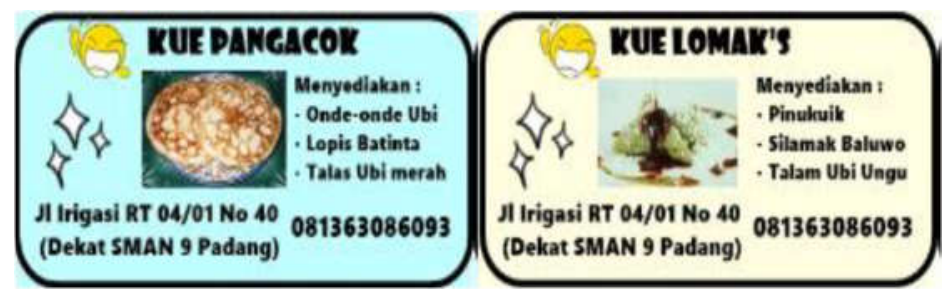

Gambar 5. Merk dagang

\section{KESIMPULAN}

1 Usaha kecil rumahan makanan tradisional merupakan salah satu penggerak roda perekonomian daerah yang memiliki potensi.untuk dikembangkan.

2. Usaha ini dapat mulai dikembangkan dengan memperbaiki kemasan, proses produksi, dan merk dagang.

3. Mengingat besarnya manfaat kegiatan pengabdian ini maka perlu diadakan pelatihan tidak saja tingkat sumatera barat, tapi juga tingkat nasional

4. Adanya kesinambungan kegiatan ini sehingga pengusaha kecil dapat terus meningkatkan kemampuan dalam mengelola usaha

\section{REFERENSI}

[1] Direktorat Statistik Ekonomi dan Moneter Bank Indonesia. 2010. Metadata Kredit Usaha Mikro, Kecil dan Menengah (UMKM). Akses tanggal 16 April 2012. http://www.bi.go.id/web/id/Statistik/Metadata/SEKDA/.

[2] Hariyanto, E. 1999. Analisis Kebutuhan Informasi Akuntansi bagi Usaha Perdagangan Eceran (Retail) di Kotatip Purwokerto.Jurnal Ekonomi Bisnis dan Akuntansi. No. 1/Vol. 1/September.

[3] Idrus. 2000. Akuntansi dan Pengusaha Kecil. Akuntansi.Edisi 07/Maret/Th. VII.

[4] Ikatan Akuntan Indonesia (IAI). 2009. Standar Akuntansi Keuangan Entitas Tanpa Akuntablitas Publik. Dewan Standar Akuntansi Keuangan Ikatan Akuntan Indonesia. Jakarta.

[5] Marbun, B.N. 1997. Manajemen Perusahaan Kecil. PT Pustaka Binaman Pressindo. Jakarta.

[6] Meutia.2010. Meningkatkan Daya Saing Usaha Kecil Menengah Melalui Kompetensi Kewirausahaan dan Modal Sosial, (Sebuah Kajian Teoritis). Jurnal Ilmiah Ekonomi Tirtayasa Ekonomi. Vol. 5 (2).Hal.167-174.

[7] Pinasti, Margani. 2001. Penggunaan Informasi Akuntansi dalam Pengelolaan Usaha Para Pedagang Kecil di Pasar Tradisional Kabupaten Banyumas. Jurnal Ekonomi, Bisnis dan Akuntansi No. 1/Vol. 3/Mei.

[8] _ 2007. Pengaruh Penyelenggaraan dan Penggunaan Informasi Akuntansi Terhadap Persepsi Pengusaha Kecil atas Informasi Akuntansi: Suatu Riset Eksperimen. Jurnal Riset Akuntansi Indonesia.Vol. 10 (3).Hal.321-331. 
[9] Presiden Republik Indonesia. 2008. Undang-Undang Republik Indonesia Nomor 20 Tahun 2008 Tentang Usaha Mikro, Kecil Dan Menengah.

[10] Hasan, Syarif, Jumlah Koperasi dan UMKM Terus Meningkat. Rakyat Merdeka Online.

(2011).

http://www.rakyatmerdekaonline.com/read/2011/12/22/49791/Syarif-

Hasan:-Jumlah-Koperasi-dan-UMKM-Terus-Meningkat-Akses. 16 April 2012. 